\title{
AN APPROACH TO PREDICTING THE INSOLVENCY OF UKRAINIAN STEEL ENTERPRISES BASED ON FINANCIAL POTENTIAL
}

\author{
Inna Neskorodeva \\ Simon Kuznets Kharkiv National University of Economics, Ukraine \\ Svetlana Pustovgar \\ Simon Kuznets Kharkiv National University of Economics, Ukraine
}

\begin{abstract}
This paper outlines the importance of defining the level of the financial potential of Ukrainian steel enterprises as a factor in preventing their financial insolvency. The findings support the selection of appropriate indexes as proxies for quantitative characteristics to determine the financial potential of companies in this industry. Levels of the financial potential of Ukrainian steel enterprises were defined using neural network technologies. The rules of 'insolvency levels classification' from an enterprise perspective were designed considering the combined effects of internal factors, relating to the enterprise's financial activity, as well as external environmental factors. Such an approach offers the evaluation of the potential of an enterprise's insolvency, taking into account its current state and the reserves for restoring its financial stability.
\end{abstract}

Keywords: Financial insolvency of steel companies, Diagnostics of enterprises insolvency, Enterprise financial potential, Enterprise financial stability.

DOI: http://dx.doi.org/10.15549/jeecar.v2i2.104

\section{PROBLEM DEFINITION}

The current problems in the Ukrainian steel industry are due to the general worsening of financial performance of Ukrainian steel enterprises, an increase in the share of unprofitable steel enterprises among registered economic entities, and an increase in the number of liquidated and bankrupt steel enterprises. The critical conditions are found in many other industrial sectors, but the steel industry is particularly suffering. Steel industry losses in 2009 represented $70.4 \%$ of the total losses among all industrial enterprises. Even though 2010 to 2012 saw rising industry yields, steel enterprises still suffered significant losses. In 2013, the amount of losses among metallurgical enterprises was 2.8 times higher than all other industry losses, and in 2014 the share of losses for steel enterprises amounted to $28.4 \%$ of the total net losses for all industrial enterprises. Given that the steel industry is of strategic importance for Ukraine's economy-representing $15 \%$ of Ukraine's GDP (State Statistics Service of Ukraine, 2015) - there is a need to develop scientific approaches to determining, and preventing, insolvencies in this industry.

\section{LITERATURE REVIEW}

A review of the economic literature shows that there has been a significant amount of work devoted to the diagnosis of the insolvency and bankruptcy of companies (Al-Kassar, Soileau, 2014; Blank, 2009; Dombrovskyi, Plastun, 2009; Fokina, 2013; Gryglewicz, 2011; Kaouthar, 2010; Kizim, Blagun, Kopchak, 2004; Klebanova, Bondar, Rayevneva, 2003; Kovda, 2010; Matviychuk, 2010; Sheremet, Sayfulin 2009; Tereschenko, 2003). All of these studies 
concluded that the probability of bankruptcy is based on either financial performance, static values, or expert estimates. Such approaches to diagnosing the insolvency of enterprises, narrow the subject of study by comparing insolvency with bankruptcy. In an earlier study, it was shown that from a theoretical point of view bankruptcy is a form of insolvency (Neskorodeva, Pustovgar, 2013). However, using measures of bankruptcy or insolvency do not allow us to either estimate the threat of insolvency in the future under the influence of destructive factors in the external and internal environment, nor do these help us estimate the potential to restore solvency.

\section{FORMULATION OF OBJECTIVES}

The goal of this paper is to provide an approach to diagnosing insolvency in the Ukrainian steel industry, taking into consideration the potential to restore solvency as well. To achieve this goal, the study has the following objectives: defining a guiding system, which characterizes the financial potential of enterprises in the steel industry; determining qualitative and quantitative levels of financial potential; and developing steel companies' perspective insolvency level classification rules relating to the level of their financial potential.

\section{PRESENTATION OF KEY RESEARCH FINDINGS}

In order to achieve financial equilibrium in an enterprise it is important to define its reserves in the case of a reduction in, or a complete loss of its solvency. A fundamental factor for determining and preventing financial insolvency for any company is its financial capacity. The essential component of a company's financial potential is expressed by whether or not there are sufficient funds to restore fiscal solvency. Based on this, our hypothesis is that the level of the financial potential of an enterprise can determine its level of financial insolvency.

This study is based on an analysis of the indicators of the financial health of the steel industry in Ukraine from 2002 to 2014 using the center of gravity method system of indicators to evaluate financial potential. These indicators are: the ratio of net assets to registered capital, the asset turnover ratio and fixed assets, the ratio of quick and current liquidity, the Beaver coefficient, rate of return on sales and return on net sales, and an integral index of the environment (Fig. 1).

From the proposed set of indicators shown above, the Beaver coefficient is characterized by the availability of the enterprise's financial resources and the possibility of its internal mobilization. General indicators such as the level of solvency and integral indicators of the environment determine the ability to mobilize from an external source.

Based on the fact that the indicators for measuring components of financially capacity have varying degrees of aggregation, it is important to separately assess the potential of internal financial ability to mobilize financial resources from external sources.

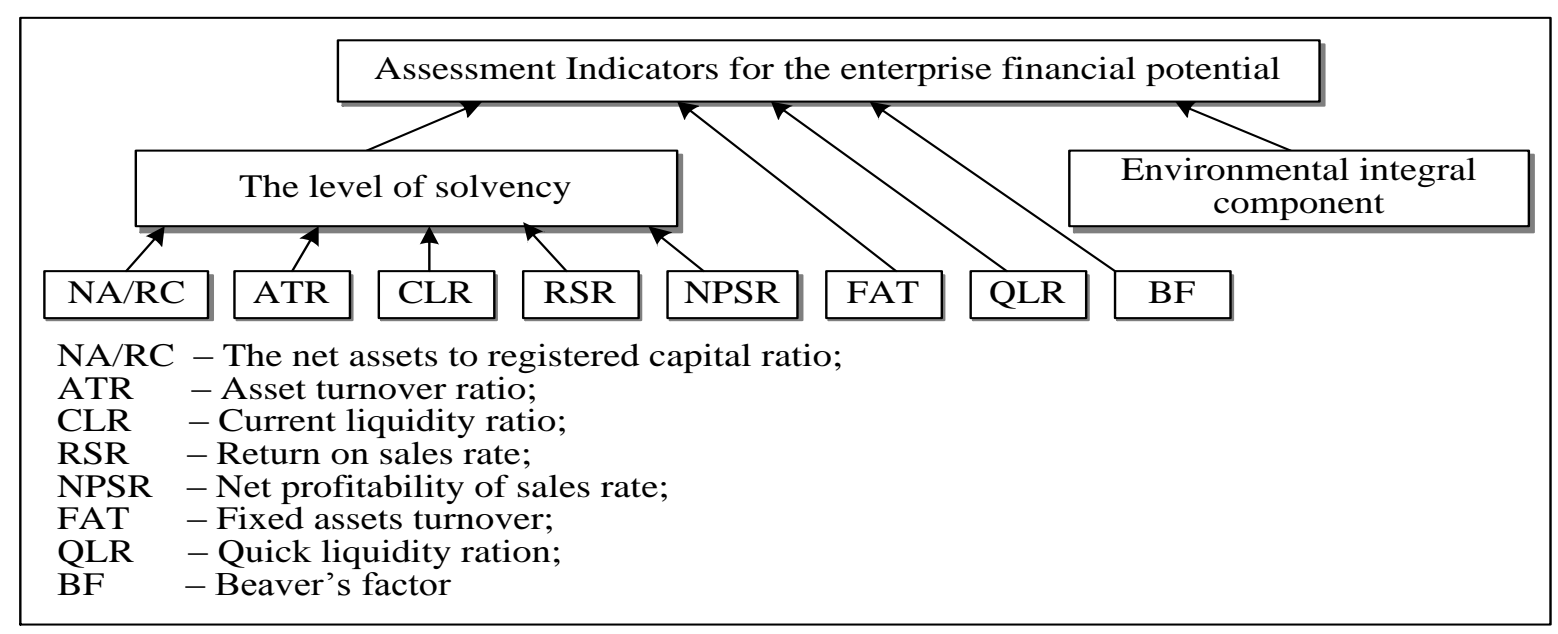

Figure 1. Indicators for the evaluation of financial capacity in Ukrainian steel enterprises Source: Developed by authors.

In order to define the internal financial potential levels of steel enterprises, Kohonen 
maps were used to identify clusters. This type of neuronet, without feedback, the setting of parameters of which is carried out though education by revealing unknown images and structures in statistical data of objects being researched (Borovikov, 2008; Buckley, 1987).

Using this method of statistical analysis to determine the levels of internal financial potential of steel plants allows us to search for patterns in large data sets using exploratory analysis (Yakhyaeva, 2006), where financial potential levels are undetermined without assigning values or classes of resulting variables, in this case, the companies'. Another advantage of the use of Kohonen maps as a type of neuronet is high accuracy due to the possibility of simulating nonlinear dependencies, which describe economic processes more accurately. This prerogative has determined the expediency of the use of Kohonen maps as a basic method of defining steel companies' financial potential. Formation of Kohonen maps in order to define internal financial potential levels of steel companies was carried out for the period of 2001-2014 using the Deductor Academic analytical platform.

Since the adequacy of the model results depends on the quality of the analytical sample, the initial stage of the clustering of steel industry enterprises was to check and clean the data to ensure accuracy while adjusting for emissions, anomalies, and missing data. These changes allowed for an adequate selection of steel companies for clustering based on the level of their internal financial potential.

The result of forming Kohonen maps to define the level of internal financial potential for Ukrainian steel enterprises is shown in Fig. 2.

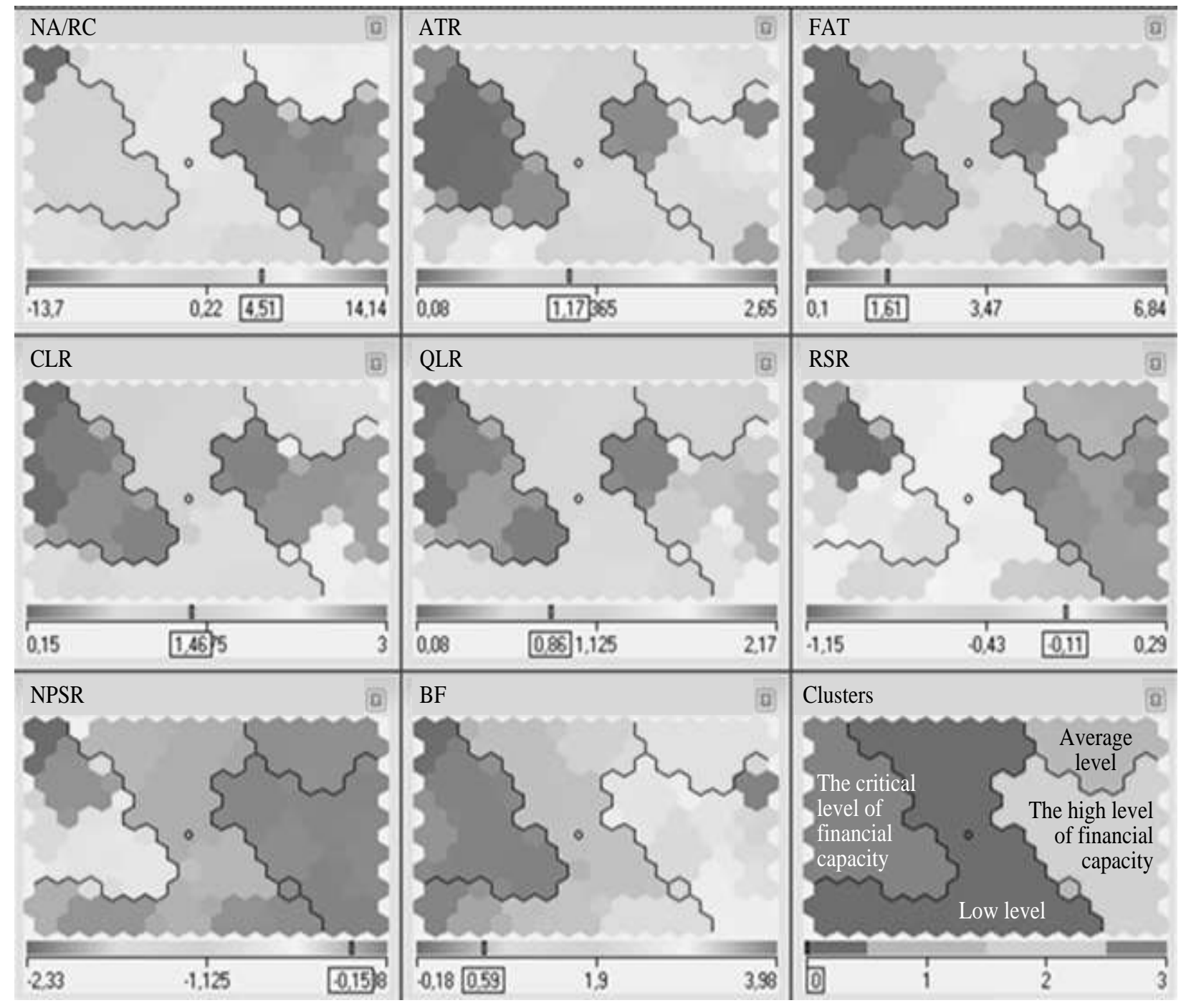

Figure 2. Levels of internal financial potential in Ukrainian steel enterprises Source: Developed by authors. 
The results of clustering of Ukrainian steel enterprises by their level of financial potential, is shown in Table 1. Enterprises with a high level of internal financial potential are characterized by high performance management, a level of current and future liquidity, and the presence of internal sources for self-financing and solvency.

Table. 1. Classification of Ukrainian steel enterprises by their level of financial potential. Source: Developed by authors.

\begin{tabular}{|c|c|}
\hline $\begin{array}{l}\text { Level of } \\
\text { Financial } \\
\text { Potential }\end{array}$ & Company \\
\hline \multirow{8}{*}{ High } & JSC «Киевский завод металлоизделий им. Письменного» (2001-2014 гг.) \\
\hline & OJSC «Запорожсталь» (2003-2010 гг.) \\
\hline & PJSC «Завод металлоконструкций и металлооснастки» (2003, 2006-2011 гг.) \\
\hline & PJSC «Черниговский завод «Металлист»(2001-2007 гг.) \\
\hline & PJSC «АрселорМиттал Кривой Рог» (2004-2008 гг.) \\
\hline & PJSC «Харьковский завод металлических конструкций»(2006-2009 гг.) \\
\hline & PJSC «Кременчугский завод металлических изделий» (2008-2013 гг.) \\
\hline & PubJSC «Краматорский завод металлических конструкций» (2012-2013 гг.) \\
\hline \multirow{7}{*}{ Middle } & PJSC «Мариупольский металлургический комбинат им. Ильича» (2007-2011 гг.) \\
\hline & OJSC «Червоноградский завод металлоконструкций» (2001-2004 гг.) \\
\hline & PubJSC «Константиновский металлургический завод» (2007-2008 гг.) \\
\hline & PJSC «Интерпайп Нижнеднепровский трубопрокатный завод»(2003-2006 гг.) \\
\hline & PubJSC «Трубный завод «Трубосталь» (2004-2005 гг.) \\
\hline & PJSC «Дружковский завод металлических изделий»(2003-2009 гг.) \\
\hline & $\begin{array}{l}\text { PJSC «Завод металлоконструкций и металлооснастки» (2001-2002, 2004-2005, } \\
\text { 2012-2013 гг.) }\end{array}$ \\
\hline \multirow{19}{*}{ Low } & PJSC «Днепроспецсталь» \\
\hline & PJSC «Авдеевский завод металлических конструкций» \\
\hline & PJSC «Металлургический комбинат «Азовсталь» \\
\hline & PJSC «Донецкий металлургический завод» \\
\hline & PJSC «Енакиевский металлургический завод» \\
\hline & PJSC «Артемовский завод по обработке цветных металлов» \\
\hline & PJSC «Макеевский завод металлических конструкций» \\
\hline & PJSC «Днепропетровский завод металлоконструкций им. И.В. Бабушкина» \\
\hline & PJSC «Днепровский металлургический комбинат им. Ф.Э. Дзержинского» \\
\hline & PJSC «Днепропетровский металлургический завод имени Коминтерна» \\
\hline & JSC «Змиевский экспериментально-механический завод «Змиевметаллосервис» \\
\hline & PJSC «Запорожский завод металлических конструкций» \\
\hline & JSC «Украинская горно-металлургическая компания - Николаев» \\
\hline & PJSC «Алчевский металлургический комбинат» \\
\hline & PJSC «Донецкий металлопрокатный завод» \\
\hline & PJSC «Кременецкий завод порошковой металлургии» \\
\hline & PubJSC «Смелянский завод металлических изделий» \\
\hline & PJSC «Луганский трубный завод» \\
\hline & PJSC «Харцызский трубный завод» \\
\hline \multirow{7}{*}{ Critical } & OJSC «Макеевский металлургический комбинат» \\
\hline & OJSC «Краматорский металлургический завод им. Куйбышева» \\
\hline & PJSC «Керченский металлургический комбинат» \\
\hline & OJSC «Кировский завод по изготовлению изделий из металлических порошков» \\
\hline & PJSC «Лозовской завод металлоконструкций» \\
\hline & PubJSC «Макеевский металлургический завод» \\
\hline & OJSC «Стахановский завод металлоизделий» \\
\hline
\end{tabular}


The middle level of internal financial potential includes businesses with a violation of solvency, for which the state of absolute solvency is sporadic. This level of financial potential is defined by a stable functioning of the enterprise at a particular moment, however, the performance in a given moment will not take away the threat of insolvency in the future caused by low efficiency and a deficit of sources for self-financing.

Enterprises, classified in the lower level of financial potential, are characterized by a violation of all the characteristics of financial status such as financial stability, liquidity and effective performance. However, despite a low level of financial performance, the enterprises in this cluster have a sufficient level of financial potential for maintaining business operations.

Enterprises with supercritical and liquidation financial insolvency do not have enough financial resources and internal sources for the mobilization of their business operations and debt repayment. These are enterprises with a critical level of internal financial potential.

The levels identified by this research are of an applied nature, because they allow forming judgments about steel companies' financial potential and by carrying out further diagnostics of the enterprise insolvency, taking their solvency restoration potential into account. However, the possible use of these designs is limited, because the model is represented in a graph form and the classification of enterprises that were not included in the custom aggregation would require rebuilding the model.

To improve the practicality of the results, quantitative criteria of steel companies clustering was defined based on internal financial potential indicator levels. Companies internal financial potential indicator levels are defined according to the actual values of the companies that, as a result of clustering, were assigned to each of the classes. Because indicator values in each cluster have a high degree of variation, for each level the confidence intervals were defined, i.e., quantitative numerical intervals, in the range of which companies financial potential indicator values vary with set probability. For indicators, distributed according to a normal distribution, defining the confidence interval is done by formulas (1, 2) (Borovikov, 2008).

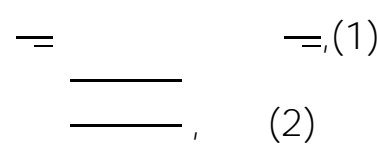

where - financial potential potential value;

- average of financial potential indicator value levels;

- amount of enterprises by the financial potential levels;

- rMS deviation of financial potential indicators;

- table value of the Laplace function argument at a given confidence level $(95 \%$.

The calculated threshold values of the financial potential indicators of Ukrainian steel companies are represented in Fig. 3.

Levels of companies financial potential allow us to determine the financial potential and the risk of Ukrainian steel companies' insolvency on the basis of calculating financial indicators and the comparison of actual and threshold values. The adequacy of the results of internal financial potential levels modeling is confirmed by the error value 0.02 for training and 0.03 for test selection, and the percentage of the recognized objects of training and test selections $(93.45 \%$ and $87.36 \%$ respectively). 


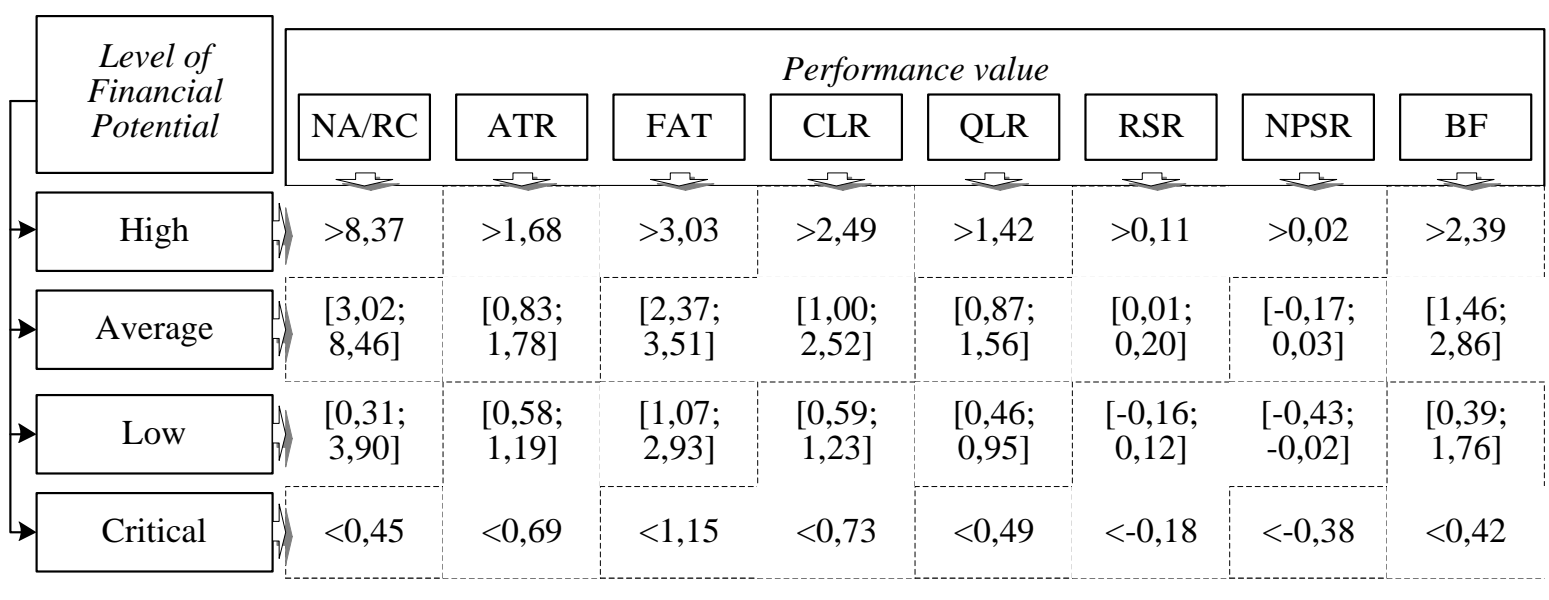

Figure 3. Ukrainian steel companies internal financial potential indicator levels Source: Developed by authors.

Custom clustering aggregation was formed and processed by the companies with the whole specter of solvency levels; from solvent, which are characterized by a high level of financial potential, to companies that are subject to liquidation due to the inability of satisfying creditors' claims by their financial potential. Levels of internal restoration potential were highlighted respectively, reflecting the whole aggregation of existing levels.

Besides the internal components of the company's financial potential, which are characterized by the availability of financial resources and the ability of their mobilization, there are also restoration reserves in mobilization of financial resources from external sources. Such resources are an increase in registered capital, increase in additional capital, and an increase in long-term and current liabilities. Increase in liabilities leads to an increase in the amount of a company's money, due to an increase in inflow, as well as to the decrease in outflow-in the case of the increase in accounts payable.

The possibility of such financial resource mobilization is determined by the state of the environment-the presence of temporarily free funds and the company's solvency level. It is because the ability of getting a bank loan and raising funds by issuing bonds, bills and the counterparties trust during the formation of the accounts payable depend on it. In view of these factors, while carrying out companies' insolvency perspective diagnostic, internal financial potential level, companies' current insolvency level and integral indicator of the environmental state should be taken into consideration, since these indicators collectively characterize the companies' solvency and the ability of its restoration.

The author's position on the approach to any company's insolvency perspective diagnostics is represented in Fig. 4. 


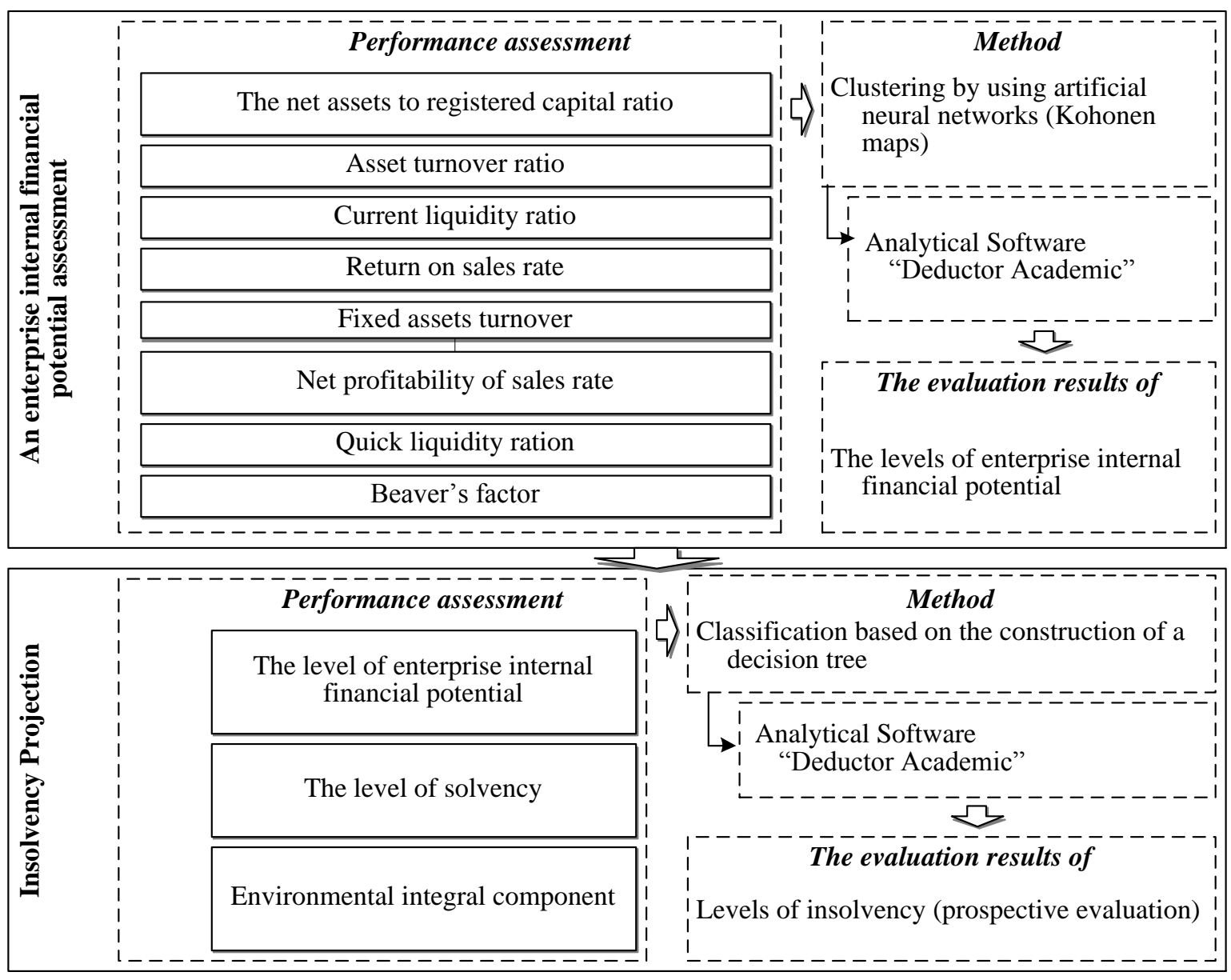

Figure 4. Technology of insolvency diagnostic Source: Developed by authors.

According to the presented technology, the insolvency perspective diagnostic of Ukrainian steel plants should be carried out based on the construction of a decision tree. A classification algorithm, at the basis of which lies search for rules, such as "if-then", represented in the form of a hierarchical structure. Decision trees are important practical tools for companies' insolvency diagnostics, because, in analysis, they can combine continuous (environmental integral indicator) and discrete (current insolvency levels and financial potential levels) variables, as well as modeling nonlinear dependencies of the objects and processes being researched, having a high modeling accuracy (Deductor, 2009).

The input dataset for the construction of the decision tree was formed due to the current insolvency levels (Pustovgar, 2015) of Ukrainian steel companies' internal financial potential levels in 2001-2014 and integral indicator of the environmental state level in the specified period (Pustovgar, 2014). The input dataset is represented by the financial insolvency indicator for the ( ) period, i.e., by the steel companies' insolvency level after a year.

For the perspective diagnostics of a company's insolvency, a condition of immutability should be set on the time horizon for financial potential levels, i.e., a company's current insolvency levels and an indicator of the environmental state for the period for which evaluation is carried out. However, since the values required for diagnostics indicators have a significant degree of temporal variation, models of perspective evaluation for more than one year have a low accuracy and adequacy. That is why a company's insolvency perspective diagnostic should be carried out for a period of one year.

A decision tree to determine the level of insolvency in the steel industry is shown in Fig. 5. 


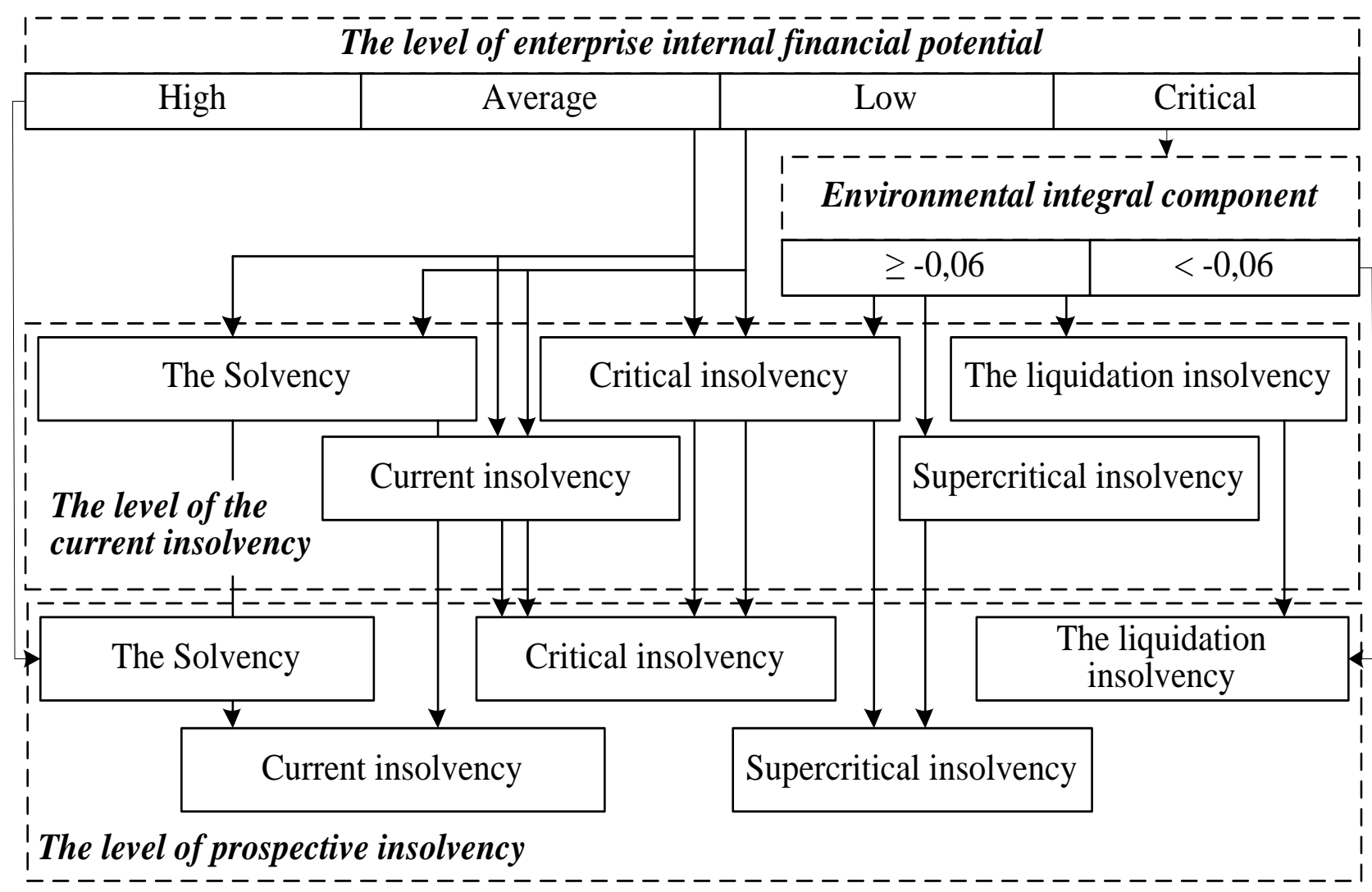

Figure 5. A decision tree showing diagnostic perspectives of insolvency in the steel industry. Source: Developed by authors.

The key criterion for defining companies' insolvency while implementing perspective diagnostics is the internal financial potential of the company. The contribution of this factor in the classification of companies' insolvency level is $68.03 \%$ The second most important factor is the company's current insolvency level, the effect of which is $26.98 \%$ The lowest value for defining the level of insolvency is the environmental factor. The significance of the integral index of the state of the environment is $4.99 \%$

The practical importance of the constructed decision tree for Ukrainian steel industry insolvency perspective diagnosis is the formulation of rules for determining the levels of insolvency (Fig. 6). 


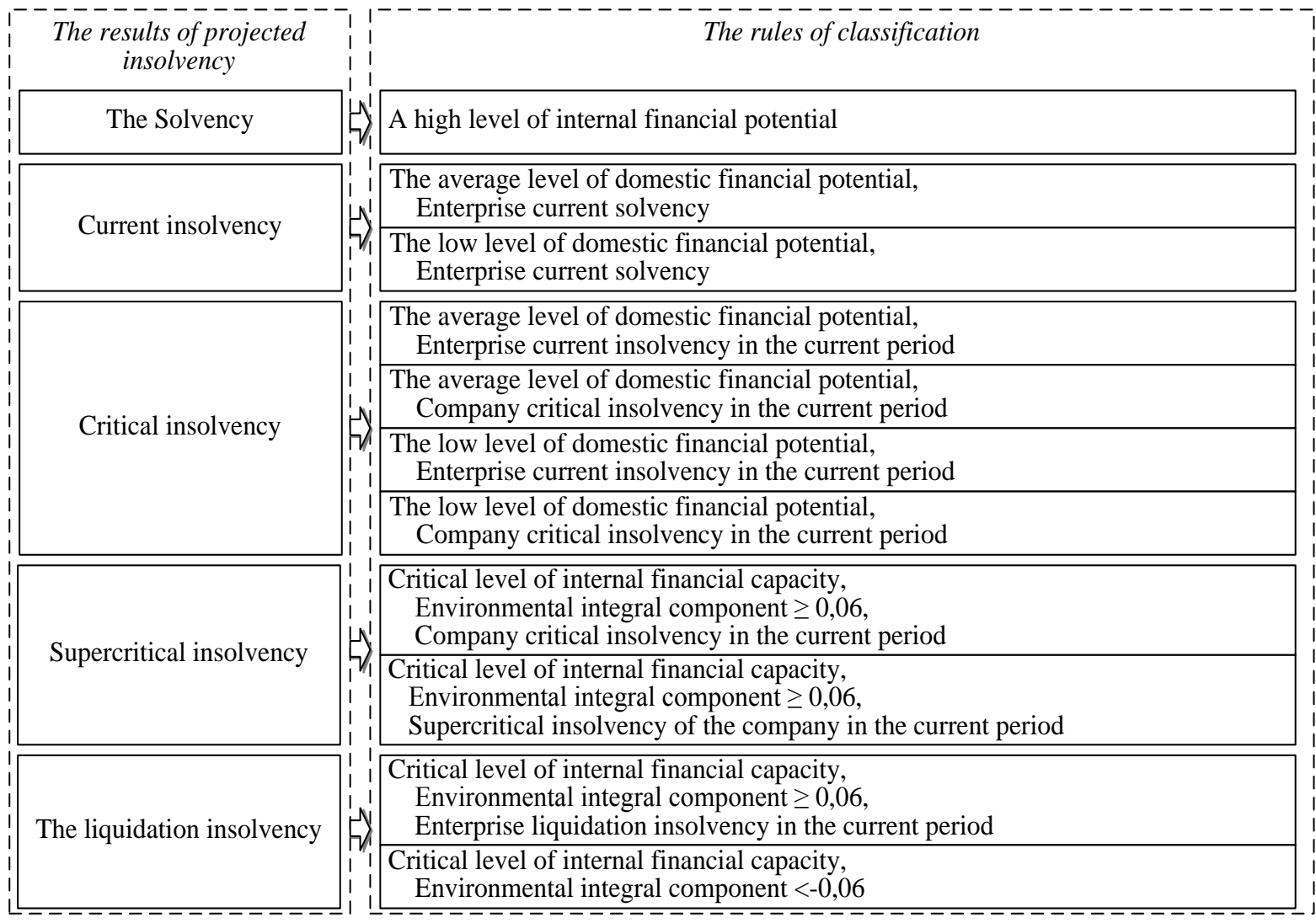

Figure 6. Rules of steel plants perspective insolvency level classification.

Source: Developed by authors.

Thus, as a result of constructing a decision tree for insolvency perspective diagnosis, it was determined that the required and sufficient condition for steel plants solvency is a high level of internal financial potential. It ensures the solvency of enterprises in the current period and allows to completely neutralize the destabilize the influence of the environment.

The deterioration of the current state of solvency in the industry and the transition from the solvent class to companies with current insolvency may be caused by a decrease in internal financial potential: from high to middle and low levels. The level of critical financial insolvency of enterprises in the long term is the result of middle and low financial potential in combination with current and critical insolvency in the current period.

The critical level of companies' internal financial potential leads to the supercritical and liquidation insolvency steel companies. Such levels in combination with the liquidation insolvency in the current period and the value of the environmental integral index (no less than 0.06) leads to the liquidation of the company. Where the value of the integral index is not less than 0.06, and the current state is not supercritical insolvency, there is a possibility of restoration of the companies' normal functioning by reorganization or implementation of sanction measures.

The possibility of the practical use of the developed rules of steel companies' insolvency perspective diagnostics is confirmed by the adequacy of the predictions: high percentage of correct classification of training and test selections ( $94.67 \%$ and $88.31 \%$ respectively), the level of support and confidence of the classification rules.

\section{CONCLUSION}

Within the framework of improvement of methodical support of companies' insolvency diagnostics, based on the use of the neuronet technologies, Ukrainian steel companies financial potential levels were defined. On the basis of the combination of internal factors of companies' financial activity and the environmental factors, rules for companies' perspective insolvency levels classification were developed, which allow to evaluate the insolvency of an enterprise taking into account its current state and its solvency restoration reserve. The suggested approach allows the implementation of the preventive 
diagnosis of companies' insolvency and defining the risk of their liquidation as a result of insolvency and lack of restoration potential. Prospects for further research in this direction are the development of a strategy to restore the solvency of metallurgical industry of Ukraine.

\section{REFERENCES}

Al-Kassar, T.A., Soileau, J.S. (2014). Financial performance evaluation and bankruptcy prediction (failure), Arab Economic and Business Journal, №9(2), 147-155.

Blank, I. (2009). Fundamentals of Financial Management. Nika-Center, Elga, 512. (Original work written in Russian).

Borovikov, V.P. (2008). Neural networks. Statistica Neural Netw orks. Publishing house «Hot Line - Telecom», 372. (Original work written in Russian)

Buckley, J.J. (1987). The fuzzy mathematics of finance, Fuzzy Sets and Systems, №21, 257273.

Deductor. Analytic Management. Version 5.2. (2009). Company BaseGroup Labs, 192. (Original work written in Russian)

Dombrovskyi, V., Plastun, O. (2009). Taking into account the phase in enterprise life cycle as a factor of its bankruptcy prevention, Actual Problems of Economics, №9 (99), 113-120. (Original work written in Ukrainian)

Fokina, N. (2013). Forecasting of crisis and bankruptcies of industrial enterprises, Actual Problems of Economics, № 2(20), 7679. (Original work written in Ukrainian)

Gryglewicz, S. (2011). A theory of corporate financial decisions with liquidity and solvency concerns, Journal of Financial Economics, №99(2), 365-384.

Kaouthar, L. (2010). Corporate governance and bankruptcy filing decisions, Journal of General Management, №4, 3-36.

Kizim, N.A, Blagun, I.S., Kopchak, Yu.S. (2004). Estimation and forecasting of insolvency of enterprises. Monograph, Publishing house «NZHEK», 144. (Original work written in Russian)

Klebanova, T.S., Bondar, O.M, Rayevneva, O.V. (2003). Bankruptcy and reorganization of enterprises: the theory and practice of crisis management. Monograph, Publishing house «NZHEK», 271. (Original work written in Ukrainian)
Kovda, N. (2010). Methodological Aspects of financial flows of the company, SocioEconomic Research Bulletin, №40, 47-59. (Original work written in Ukrainian)

Matviychuk, A. (2010). Bankruptcy prediction in transformational economy: discriminant and fuzzy logic approaches, Fuzzy economic review, №1, 21-38.

Neskorodeva, I., Pustovgar, S. (2013). Studying the essence of «enterprise insolvency» economic category, Economics of Development, №3(67), 68-72.

Pustovgar, S. (2015). Determination of the levels of enterprises' insolvency in a steel industry of Ukraine, Economy. Finance. Law, №6/1, 15-21. (Original work written in Ukrainian).

Pustovgar, S. (2014). Determination of Complimentary and Destructive Environmental Factors, Evaluation of Their Influence on the Risk of Financial Insolvency for the Metallurgical Enterprises of Ukraine, Business Inform, №11, 114-119. (Original work written in Ukrainian).

Sheremet, A., Sayfulin, R. (2009). Finance of Enterprises. Publishing house «INFRA-M», 387. (Original work written in Russian). State Statistics Service of Ukraine (2015). Official web site. Retrieved August 3, 2015 from http://www.ukrstat.gov.ua

Tereschenko, A. (2003). Discriminant model of integrated assessment of the financial state of the enterprise, Economy of Ukraine, №8, 38-44. (Original work written in Ukrainian)

Yakhyaeva, G.E. (2006). Fuzzy sets and neural netw orks. Publishing house «Binom», 482. (Original work written in Russian) 


\section{ABOUT THE AUTHORS}

Inna Neskorodeva email: innanesk@rambler.ru

Dr. Inna Neskorodeva is an Associate Professor in the Department of Finance at Simon Kuznets Kharkiv National University of Economics. She has published over 60 research papers, including five monographs, two refereed academic research articles, and three textbooks approved by the Ministry of Education of Ukraine. Inna holds the graduate certificate from Springer Author Academy. She served as Dissertation Chair for two candidates in field of economics. Dr. Neskorodeva is an expert on investment in stock market and specializing in risk assessment of the Ukrainian bond issuers.

Dr. Svetlana Pustovgar is a Lecturer in the Department of Finance at Simon Kuznets Kharkiv National University of Economics. She has published 20 scientific research papers, one monograph book, and one articled in peer-reviewed journal referenced in Scopus. Svetlana is an author of scientific research with concentration on evaluating companies' insolvency which is incorporated in practical manual used by Ukrainian rating agency "Rurik". 